\title{
Public financial management in Indonesia: Review of Islamic public finance
}

\author{
Aan Jaelani \\ Faculty of Shari'a and Islamic Economics \\ State Islamic Institute Syekh Nurjati Cirebon \\ Jl. Perjuangan By Pass Sunyaragi Cirebon 45132; \\ Email: \\ iainanjal@gmail.com \\ Website: \\ https://ideas.repec.org/f/pja475.html \\ http://econpapers.repec.org/RAS/pja475.htm
}

Presented at the International Conference on Islamic Economics and Business

(ICONIES): Strengthening Islamic Economics in Facing Asian Economic

Community (AEC), the Faculty of Economics, Maulana Malik Ibrahim State Islamic

University, Malang, November 2-3, 2015

\begin{abstract}
Public financial management by the government is very important in view of the level of welfare in Indonesia is still low, as there are still much poverty with the level of fulfillment of the needs of low, corruption that occurs in every area of government, income distribution is uneven, low economic growth, and various irregularities other budget. With a qualitative approach that emphasises the phenomenon of the social reality and the country's financial management practices in Indonesia, the approach to history and historical analysis is able to provide solutions to the existing problems. Reviewing public financial revenues and government spending become instruments in creating public welfare.
\end{abstract}

Key Words: Budget management, public finance, budgeting,welfare

JEL Classification: B15, H2, H6, P5

\section{A. Introduction}

In the study of economics, the term public finance or financial state, as revealed Harvey S. Rossen and Ted Gayer (2008: 2), emphasis on rationalization of the state's role in economic life on the basis of market failure and the need to modify the distribution of income resulting from the process mechanism market in accordance with common norms and distributive justice. According to Bernard Salanie (2000) and Amihai Glazer and Lawrence Rothenberg (2001), other hypotheses show to study the social welfare function to be maximised by the public authorities (state).

Musgrave and Alan Peacock (1958) explore the study of public finance conducted in the 1950s showed a belief in the interests of maximising social welfare published through some classic article on public finance in 1958, then some important material in the study was still being debated by the economists until now. In fact, the study of public finance has become the dominant theoretical approach in addition to other approaches or more to fill the literature with issues of public sector. 
The development of social welfare approach to a major part in the assessment of public finances, as an initial contribution to the theory of taxation undertaken by economists earlier, for example, Francis Y. Edgeworth (1897), Ramsey (1927), Pigau (1951), Samuelson (1954), and Walter Stanley L. Winer and Hettich (2004: 1-2), the theory of public goods, and the implementation of social welfare functions in the public economy, which strengthen and develop the previous theory through critical approaches in the literature on optimal tax.

Factually, the current global economic developments have implications for the welfare state. Limits and strength of the nation-state is fading, dispersed to the locality, independent organisations, civil society bodies supra-national (such as NAFTA or the European Union), and multinational corporations. Ramesh Mishra (2000) states that globalisation has limited the capacity of the nation-state in conducting social protection.

In line with recent economic developments, the challenges of the global economy are expected to be faced in 2015 include: (1) global economic uncertainties triggered by the economic slowdown and crisis in various countries; (2) the risk of volatility of commodity prices in global markets, especially crude oil prices; (3) a commitment to participate and support the ASEAN Economic Community (AEC); and (4) the implementation of the post-2015 global development agenda.

Meanwhile, the domestic economic challenges expected to be faced in 2015 include: (1) the acceleration of economic growth is slowing; (2) the risk of the financial market in the country; (3) imbalance in the balance of payments; and (4) reducing social inequalities.

By paying attention to the achievements RPJMN second phase 2009 - 2014, sustainability RKP 2014, the challenges of global and domestic economy are expected to be faced, and the main focus of RPJMN third from 2015 to 2019, the theme RKP 2015 is "Continuing Development Reform For Economic Development Acceleration Equitable ". As the elaboration of themes RKP 2015, identified 25 strategic issues that will be the focus and assessed as having a high leverage to the economy and improving the people's welfare.

In the face of ASEAN Economics Community (AEC), economic activities can not pay attention to ethical issues that could lead to all the players in the economy will collide interests, so that this condition may create a force that can destroy other economic actors. Therefore, Islamic business ethics becomes a frame of reference as a form of morality for economic actors. Business ethics can help prevent market distortions so that various forms of economic practice provides mashlahah for human life as a whole.

Therefore, the role of the state in the management of public finances is very important given the still low level of social welfare, poverty is still perceived by the public, the practice of corruption in every field of governance, unequal income distribution, low economic growth, and a variety of budget irregularities. These problems require solutions, one of which is reviewed from the perspective of Islamic public finances.

\section{B. Theory of Public Finance}

According to Richard A. Musgrave (1959: 7), public finance is the study of the economic activities of government as a unit. Carl C. Plehm (2002) and Robin Boadway (2002) (in S. Winer and H. Shibata, eds. (2002: 47-68) emphasise that 
public finance is the study of the use of funds by the government to fulfil payment government activities. Therefore, the above definition makes public the financial terms identical to the terms of state finances, public economics and public sectors of the economy.

The term of public finance has a meaning quite debatable. It is admitted by Harvey S. Rossen and Ted Gayer (2008: 2), that the finance term meaning "financial" or related to money (money). In these terms should not be construed as a purely financial, since the fundamental issues were not studied finance. It is also caused due to the focus of this subject are sometimes unclear. Thus, the public finance focusing on the study of how the government in the allocation of resources and distribution of income. This discipline also discussed the activities of government spending and income growth (Guritmo Mangkoesoebroto, 1999). Therefore, public finance is a branch of economics, not financial science. In addition, studies of public finances are much use of other terms, such as public sector economy and public economy.

Harvey S. Rossen (2002: 1) defines that public finance is the branch of economics that studies the taxing and spending activities of government. Critical issues in the study of public finances is not a financial issue though related to financial aspects, but the main problem associated with the real sources. Public finance studies using positive analysis and normative. Analysis positive emphasise issues concerning the causes and consequences of something, whereas normative analysis focuses ethical issues in public finance.

Therefore, Harvey S. Rossen and Ted Gayer (2008: 1) assess the modern public finances associated with the macroeconomics of government functions, how the government and the allocation of resources and distribution of income. At the other important part, the government's macroeconomic function associated with the use of taxes, spending and monetary policy at the level of completion of unemployment and price levels.

Public finance is the study of government intervention in regulating the market (market place) (Harvey S. Rossen and Ted Gayer, 2008: 6). With different views, according to the orientation of the flow of Continental, public finance is the study of how society participation through political and fiscal institutions to achieve patterns and fiscal purposes. Definition of public finances by Continental flow is joined by Buchanan (1967: 10-13).

The term of public finance for economic studies in Indonesia usually uses the term state financial science. In view Soetrisno PH (1981: 7-8), the country's financial science is the study of expenditures and receipts by the government and the state. Whereas in view Suparmoko M. (2003), the science of state finances is part of economics that studies of government activities in the economic sector, particularly regarding the receipt and expenditure along with its effects on the economy.

In the countries of "Anglo-Saxon", public finance or financial state as a science is seen as a branch of economics, whereas in mainland Europe, public finance is seen as a branch of political science. According to Nurdjaman Arsjad, et.al. (1992) in the literature in countries "anglo saxis", public finance is often called "public finance", the term "public" is often confusing and is not the right term (precise term). In the literature of state finances (public finance), the term "public" usually interpreted to mean the "government". According to Suparmoko (2003), "public sector" and "government" are identical, even has said also that financial 
studies state is identical with the study of the role and activities of the government in the public sector.

In a broad sense is actually the term "public" not only describes the activities of the government alone, but also describes the "utility" (which addresses the needs or the lives of many people), and also a charitable association activities (charitable associations). The term "public finance" as explained in advance interpreted in the narrow sense of "government finance", was the meaning of "finance", which describe all activities (government) in the search for sources of funding and then how those funds are used to achieve government goals.

Based on the description of the meaning of public finances, then discipline is most do not have a scope that includes: (1) the state expenditures; the mechanisms through which the state government spending to develop the course of the financial economy in accordance with the pattern of demand and supply. In carrying out their functions of government not only use money, but also includes economic resources, including the use of human resources, natural, equipment, capital, goods and other services; (2) revenues; discusses some of the sources from which countries earn revenues / funds; (3) the state administration; concerning all financial activities including all the problems of the state administration; (4) stabilization and growth; to discuss the government's economic policies in a specific time and situation; (5) the effect of state budget revenues and expenditures to the economy, especially the impact on the achievement of objectives of economic activities, such as economic growth, price stability, income distribution, and increased efficiency, as well as the creation of employment opportunities.

Financial state has a body of knowledge that is compact, single and homogeneous, main discussion contained in state finances as studies and science are: (1) government expenditures; (2) sources of revenue state in which the tax is the most important source of revenue (government revenues and taxes); (3) government borrowing and indebtedness; (4) administration or engineering fiscal that addresses the legal and financial administration of the country; (5) fiscal balance between the central government and local government (intergovernmental fiscal relationship), a study in the state finances increasingly important and prominent; and (6) fiscal policy is to study the role and influence of state finances on national income, national income distribution, employment, prices and also the efficiency of the allocation of resources.

In the view of Harvey S. Rossen and Ted Gayer (2008: 2), the scope of public finance include public finance, state, and ideology, economic prosperity (economic welfare), public spending (public goods and externalities, political economy, education, cost analysis -benefit, social insurance, income distribution, taxation, and so on).

Thus, the public finance or financial state is one study of what it should be or is normative economics. Suppose we want to achieve certain goals such as economic growth or income distribution more equitable, then we have to determine a policy that we must apply in reaching these goals.

Public finance, as well as other social science, are positive and normative. Public finances as science studies can be divided into "positive public finance" and "normative public finance". Public finances "positive" is the study of the facts, circumstances and relationships between variables with respect to the government's efforts in seeking funds and use of funds, such as how the tax system and tax 
structure today, study to circumstances and budget systems these days and so forth , So, in a "positive public finance", we are trying to describe, explain, and predict what happens in state finances.

As for public finances "normative" is the study of state finances on ethics and values of view (value judgment), namely how the activities of state finance, taxation, spending and borrowing countries could create efficiency of resource allocation, macroeconomic stabilisation, equity or income distribution, etc. Thus, the study of "normative public finance" more range in the area of state financial policy issues (fiscal policy). This is influenced by ideological views, which are divided into two primary approaches, as described Harvey S. Rossen and Ted Gayer (2005: 2-5), namely: organic view of government, and the mechanistic view of government.

In this case, government policies relating to revenue and expenditure to improve the economic stability needs to be done in the form of fiscal policy. According to Soediyono R. (1992: 95), fiscal policy or fiscal policy is an action taken by the government in the form of state budget revenues and expenditures in order to influence the course of the economy.

Samuelson (2008) explains that the government has been playing an increasing role in the modern mixed economy system. This is reflected in the growth of government spending, income generation by the state, and settings directly from economic life. The change of government functions is reflected in government operations include direct supervision, the social consumption of public goods, the country's financial stability and monetary policy, government production, and welfare expenditure.

Therefore, the mainstream economic theory provides a framework for the analysis of public finances. Therefore, the rational theory could be used to assess public finances in an area of application of microeconomics. As is the case in other branches of the economy, public finance normative framework includes economic welfare, one of the economic theory that focuses on the study of social welfare for an economic alternative government. In this case, according to Harvey S. Rossen and Ted Gayer (2008: 2), focusing on the economic welfare conditions in which the allocation of economic resources achieve Pareto efficiency.

Harvey S. Rossen and Ted Gayer (2008: 2) also explained that "Paretoefficient defined as an allocation such that the only way to a make one person better off is to the make another person worse off. Pareto efficiency seems a reasonable normative criterion-- if the allocation of resources is not Pareto efficient, it is "Wasteful" in the sense that it is possible to the make someone better off without hurting anybody else. A stunning result of welfare economics is that if two assumptions are satisfied, then an economy will achieve a Pareto-efficient allocation of resources without any government intervention. The assumptions are: 1) All producers and consumers act as perfect competitors; that is, no one has any market power. 2) A market exists for each and every commodity. In a way, this result formalises an old insight: when it comes to providing goods and services, free enterprise systems are amazingly productive. "

In Islamic economics, the study of public finances can be traced in the epistemology of the Koran. M.A. Choudhury (1992) asserts that the epistemology of the Koran on all the socio-science used to develop a political theory of Islamic economics, as an illustration of relationship the process of interactive-integrative about formation and institutional behaviour. This is called the process of suratik as 
the reference for the alternative causal models of circular and continuity of the unity of reality. Suratik process essentially as a form of emerging and developing methodologies circularly result from theological worldview.

In the study of economic policy, M.A. Choudhury (1993) states that theorising and practice of Islamic law and their settings through the institutionalisation of shura' during the scholastic Islam has set the strength, prosperity, production, and distribution in the community. There is no conceptualization of science or popular institution building and the restrictions that appear to regulate a development of thinking and empowerment at this time. Thus, the Muslim community to develop itself from the principles of monotheism derived from the Koran.

Political study of Islamic economics is the public interest. Institutions ijma' (agreement ulama) and shura' (deliberation) being the main conceptions in the supervision of decision-making in government. Social control institution, al-hisbah, expressed al-Mawardi, Ibn Taymiyyah, and other figures into the source of the price control that requires the transformation of ethics policy endogenous-market interrelations (M.A. Choudhury, 1992). Sabahuddin Azmi (2002: 23) states that public finances (public finance, al-amwal al-'ammah) are one branch of economics that addresses the procurement, maintenance, and expenditure of the resources needed to carry out the tasks of government. Public finances also related to financial aspects of government business.

Public finances in the context of shari'a become an integral part of human life in the relationship, particularly in relation country-folk. In a sense, the human relationship with another human being has a free space, but this relationship has a transcendent value as a form of economic activity that will be accountable to God. Thus, human freedom, economic realities, and accountability to God be the framework for economic actors, including the authorities, so that economic activities can not be separated from how intentions - 'amal (action) - business purposes. M.A. Choudhury (1992) asserts that the reality is the underlying economic activity should be conceived of epistemology tauhidi - in terms of economic activities closely related to the concept of God, that God as Absolute Reality.

Therefore, the state must provide the necessary infrastructure for economic development and common prosperity. Even this institution shall organise and finance the expenditures required by the public service. Public services and social obligations should be standardised in the public interest. On the other hand, according to alMawardi (1996: 245), in a case of the budget deficit in the public interest, it can be assigned a new tax or make loans to the public. This policy had also done the Prophet to finance the war and the interests of other public goods.

\section{Methodology}

Studies on global economic challenges in the management of public finance budget Islam's perspective using a qualitative approach to unravel the phenomenon of reality that can be traced scientifically about the management of public finances. Therefore, according to Taufik Abdullah (1987: 9-12), this study can not be separated from understanding the history of Islamic economic thought, particularly public finances, so the textual study is complemented with the study of social reality and its historical dynamics. 
This study also includes exploration of analysis philosophically within a certain time in the past and present, the methodological approach history. M. Nazir (1984: 141-143) states that this historical approach is the track record of the previous period, in this case, contain public financial management practices.

Meanwhile, an assessment of public finances Islam more historical than the description of which is an analysis and place them in the economic discussion. Some of them, Aghnide (1969) who wrote Mohammaden Theories of Finance, Ben Shemesh (1965) has written Taxation in Islam as a form of translation of some parts of the Kitab al-Kharaj written Abu Yusuf, Yahya ibn Adam and Qudamah, Abdul Azim Islahi (2004), Contributions of Muslim Scholars to Economic Thought and Analysis (11-905 AH/632-1500 AD), Adiwarman Azwar Karim (2006) writes about Sejarah Pemikiran Ekonomi Islam, Irfan Rana (1977) in the Economic System under Umar the Great, SA Siddiqui (1965) who wrote the Public Finance in Islam, and Aan Jaelani (2013) in Institusi Pasar dan Hisbah: Teori Pasar dalam Sejarah Pemikiran Ekonomi Islam.

Other works for Islamic public finance category, such as 'Abd al-Salam Balaji (2000) in al-Maliyat al-'Amma' inda al-Mawardi wa-Ibn Khaldun, Yasin Ghadi (1994) in al-Amwal wa-al-Amlak 'Amma al-fi al-Islam wa-al-I'tida Hukm 'alaiha, Mahmud Julayd (1995/1415) in Qira'at fi al-Maliyat al-'Amma fi al-Islam, M. Nejatullah Siddiqi (1992/1413) through his work, Teaching Public Finance in Islamic Perspective, Zafar Iqbal (1989) in Islamic Perspective on Public Finance, Ziauddin Ahmad (1989) in Public Finance in Islam, and Mohammad Akram Khan (2009) in Public Finance in Islam (A Bibliography of Works in English).

The collected data will be analysed using content analysis method (see Klaus Krippendorf, 1991: 15) and the critical historical method (see Noeng Muhadjir, 1998: 49-51). The data collected will do the screening into relationships fact that form understandings, then the description presented in the form of descriptive-analytic and descriptive narrative, so it will be obtained a conclusion of the exposure that.

\section{Results and Discussion}

\section{Public Financial Management and Budget in Indonesia}

With the increase in the financial resources of the state, public financial management systems that either become much more important in order to guarantee the quality of the budget expenditure and reduce the risk of corruption. With a growing number of public financial resources that will be spent on the government, demand planning, budgeting, and procedures for implementing the budget will also increase. Modernization of systems, processes, and institutions within the budget cycle is required in order to achieve the goals of the increase in spending priorities of government development programs, such as reducing poverty and increasing economic growth. Furthermore, the quality of public financial management and results-oriented necessary to maintain public support for increased spending and government revenue.

Indonesia has made great progress in establishing a regulatory framework for the management of public finances and increase transparency. Determination of the law on state finance, treasury law, the law on financial audit of state and law of the national development planning are important steps that bring Indonesia to the financial practices of international standard. 
The Ministry of Finance has undertaken a massive reorganisation to improve and enhance their functions. All the law now been implemented, and the most obvious are to make the central government budget in accordance with classification standards of international finance (GFS), the establishment of Account Treasury Single (Treasury Single Account/TSA), as well as the unification of postal development budget and the previous routine separately, although lately, the public financial management reform is already showing progress, weaknesses in public financial management framework is still going on, especially in terms of planning and budgeting, budget execution, accounting and reporting, and external accountability. Although, the general legal framework is now available, still faces serious challenges in establishing these reforms through the correct implementation and by rearranging the underlying process.

So far, some of the main indicators of the performance of the government budget have not been improved, especially regarding indicators of budget realisation. Realisation of central government spending always deviates from the original plan. Subsidies and budget transfers to local governments tend to be underestimated, which resulted in excess expenditure overall.

There are three basic reasons that may explain the difficulties in the implementation of the budget efficient: (i) the preparation of the budget; (Ii) a rigid implementation of the budget; and (iii) implementation bottlenecks.

First, the lack of preparation of the budget, especially the much lower estimates of oil prices, has led to the revision of the budget that could reach three times. Second, the government is still implementing the budget execution process rigid. Detailed control of the input intended to ensure that the budget composition according to political priorities and the budget will not be altered during its execution. Documents expenditure (DIPA/Daftar Isian Penggunaan Anggaran), although now it has been issued at the beginning of the fiscal year based on budget per post (line items), so less flexible to make adjustments in the composition of the inputs needed to carry out an activity. Third, the slow disbursement strongly associated with advanced issues related to institutional capacity. in particular, the capacity to complete the procurement process timely procurement procedures in accordance with the provisions of increasingly stringent.

The Law of the Republic of Indonesia No. 17/2003 on state finances has been reformed significantly on budgeting system that has for decades applied in Indonesia. In short, the factors that encourage reforms in budgeting are:

(1) There are several aspects of the budgeting process in Indonesia that hinder the distribution of budget funds to the various programs;

(2) Estimated revenue and budget projections are not prepared within a framework of macro;

(3) There is no framework budget unification (unified framework for budgeting) given the recurrent and development budget is prepared separately;

(4) budgeting system that applies engenders a lack of information on the results of a program;

(5) Implementation of the budget and monitoring still become weak;

(6) The structure of budget allocations fairly detailed, indirectly reflect the strong control, but the realisation is considered cause various aberrations $(\mathrm{KKN})$ and leakage.

The main points are the most important budgeting reforms include: 
(1) Application of budgeting approach to the medium-term perspective;

(2) Integrate (unifying) or integrate regular budget and development budget;

(3) The application of performance-based budgeting.

Prior to the enactment of Law No. 17/2003, differentiated state spending on routine expenditure and development expenditure (dual-budgeting). Routine expenditures are defined as expenditures for operational purposes to carry out routine activities of government. Routine expenses include personnel expenditure, expenditure items, interest payments, subsidies and other expenditures. While development expenditures are defined as expenditures that produce value-added assets, both physical and non-physical, which is carried out in a given period (Anggito Abimanyu, 2004).

The development expenditure is expenditure relating to projects that include capital expenditure and support expenditure. The capital expenditures include land acquisition, procurement of machinery and equipment, building construction and the network (infrastructure), and capital expenditure of physical and non-physical. Meanwhile, support expenditure allocated to support the implementation of the project consists of salary/wages, materials, travel, and other support expenditure.

Separation of the regular budget and the development budget was originally intended to emphasise the importance of development, but in practice has shown many weaknesses. First, duplication between recurrent and development expenditure due to lack of traction on the separation between the operational activities of the organisation and projects, especially projects of non-physical. Thus, the performance is difficult to measure because the allocation of funds does not reflect the real conditions. Second, the use of "dual budgeting" encourage dualism in the preparation of the forecast budget line output (Mata Anggaran Keluaran/MAK) due to the kind of shopping, there is the MAK that was created for recurrent and there is another set MAK development spending. Third, analysis of expenditure and the cost of the program is difficult because a routine budget is not limited to spending on operations and development budget expenditures are not limited to expenses for investments. Fourth, the project received a development budget is treated the same as the unit of work, namely as accounting entity, even though the project is only temporary. If the project has been completed or terminated there is no continuity in accounting for assets and liabilities owned by the project. This is in addition to creating inefficiency in financing government activities, also created uncertainty linkages between outputs/outcomes achieved with the budgeting organisation.

Furthermore, as mandated by Law No. 17 / 2003, the budgeting system refers to practices that apply internationally. According to GFS (Government Financial Statistics) Manual, 2001, the state budgeting system implicitly uses a unified budget system, where there is no separation between routine and development expenditure, so the classification according to the economy will be different from previous classifications. In this case, government expenditure by economic classification grouped into: (1) compensation for employees; (2) the use of goods and services; (3) the compensation of fixed capital related to the cost of production carried out by units of government organizations; (4) interest on debt; (5) subsidies; (6) grant; (7) social benefits; and (8) other expenses in order to transfer in the form of money or goods, and purchasing goods and services from third parties to be sent to other units.

In carrying out changes in the format and structure of government spending has been done by making adjustments, but still refers to GFS Manual 2001 and Law 
No. 17/2003. Some important notes related to changes and adjustments to the format and structure of the new state spending, among others:

First, in the format and structure of the I-account of a new, state spending remains separated between central government spending and spending for the region, because the expenditure for the applicable region during this time can not be classified into one of the headings of expenditure as stipulated in Law No. 17 / 2003; Second, all state expenditures in form of assistance / subsidy in the format and the new structure is classified as a subsidy; and third, all in public expenditure during this 'contain' the name of others are scattered in almost all state spending items, in a format and a new structure is classified as other expenditures.

With a variety of changes and adjustments to the state budget by economic classification (type of expenditure) consists of: (i) personnel, (ii) spending on goods, (iii) capital expenditures, (iv) interest payments, (v) subsidies, (vi ) grants, (vii) social assistance, and (viii) other expenditures. While shopping for the area, as applicable during this consists of: (i) the balance funds, and (ii) special autonomy funds and adjustments. With the change in format and structure of state expenditures by type of expenditure then automatically there is no separation between recurrent and development expenditure (unified budget).

Budget management is essential to achieving economic development goals. Economic development is essential for well-being. Globally and in particular in the advanced industrial countries, economic growth has strengthened integration and social solidarity, as well as expanding the capabilities and access to health care, education, housing, and social protection. However, analysis of Edi Suharto (2005: 48 ), in many developing countries, globalisation and free market economy has widened the gap, causing environmental damage, undermine the local culture and language, and exacerbate poverty.

Policies of privatisation, free market and 'structural adjustment' which emphasised the international institutions have pushed developing countries into situations in which they live impoverished population without protection. While economic growth is important, but it does not automatically protect people from risks that threaten it. Therefore, some developing countries began to implement social policies concerning the organisation of social security schemes, although it is limited and is associated with status and categories of workers in the formal sector.

In the analysis Faridi (1983), public finances can not be detached from reality the role of state and government in any discussion of public policy. While conventional theory focuses on the idea of social objectives based on individualism and self-interest, whereas public finances Islam has an approach based on the overall view of the purpose of the life of every Muslim and urgency of the role of the state in an Islamic society.

\section{System of APBN in Indonesia with Performance-Based Budgeting}

In line with the mandate of Law No.17 / 2003, will also be fully implemented performance-based budgeting in the public sector, so that the use of the budget can be assessed in efficacy and usefulness to society. As is understood, as long as we apply traditional budgeting or also known as line-item budgeting. Line-item budgeting has a number of key characteristics, among others, its main purpose is to conduct financial controls, very oriented to the input of the organization, its adoption through incremental approach (a gradual rise), and not infrequently in practice 
wearing 'ability to spend or absorb budget "as one an important indicator to measure the success of an organization.

In practice implementation, characteristics as above contain many weaknesses. In a regime that is loaded with KKN (Korupsi, Kolusi, Nepotisme) or corruption, collusion, and nepotism characteristics related for the purpose of financial control, are often carried out only limited administrative aspects only. It is possible to do because it is supported by other characteristic that is strongly oriented towards organisational input. Thus the budget system does not provide information about the performance, so it is very difficult to control the performance.

Other weaknesses related to the characteristics of incremental budgeting approach, is to establish a budget plan by raising a certain amount on the amount of the previous budget or running. Through this approach, a profound analysis of the level of success of any program is not done. The result is no available information about the logical and rational allocation plan the coming year's budget. Who gets how many or which units are often based on historical records only and not goaloriented organisation.

Other weaknesses related to the use of "the ability to spend the budget" as an indicator of success. What often happens in practice is the behaviour of bureaucrats who are always trying to spend the budget without associated with yield and quality. Of course, this situation gets worse if it is associated with the character of the bureaucrats who tend to be a budget maximizer.

As a result of the weaknesses of the above, it is a major problem faced by line-item budgeting system is the problem of effectiveness, efficiency problem, and accountability problems. But even if the system is transparent, then the information can be received by the public is not very important, because it is only concerned with organisational input.

In response to the problems of the line-item budget system above, Law No. 17/2003 introduces performance-based budgeting system. Performance-based budgeting is budgeting system oriented to the organisation's output and are closely linked to the vision, mission and strategic plan of the organisation. Performance budget to allocate the resources to the program rather than on purely organisational unit and put on output measurement as an indicator of organisational performance. Furthermore, he attributed the cost to the organisation's output as an integral part of its budget in the file.

The purpose of the determination of output measurement associated with the cost is to be able to measure the level of efficiency and effectiveness. It is both a tool to be able to follow the principle of accountability, as received by the public, in the end, is the output of a process of the bureaucratic activity.

Roy V. Solomon (2003: 34-39) states that measures the performance of the budget system performance-oriented useful for the people's representative institutions (DPR/Dewan Perwakilan Rakyat or DPRD/Dewan Perwakilan Rakyat Daerah) while performing the function of shaping policy, budget setting function, and the function of supervision, For the top management of the executive branch is useful for management control and quality control and can be used for employee incentive system. And ultimately for the community to provide clarity on the performance and accountability of government (The World Bank, 1998). 


\section{Budget Management and Good Governance}

In order structuring accountability of state finances, Abdul Hakim (2006: 2025), Bappenas (2002), and Bintoro Tjokroamidjojo (1995) illustrates that the formation of the state finance refers to the norms and principles as follows: first, transparency and accountability state finances. Transparency of state finances is one of the requirements for ensuring good governance, clean and responsible. Given the government's conduct is one means of evaluating the achievement of the performance and responsibility of government welfare society, the state finance should provide clear information about the goals, objectives, outcomes and benefits society of an activity or project is budgeted. Moreover, any funds raised, they should be accountable.

Second, the state financial discipline. State finances are arranged to be done based on the principles of efficiency, appropriate, timely and accountable. The choice between shopping routine by goods spending development/capital should be classified clearly, in order to avoid a second confound of budget properties which can lead to waste and leakage of funds. Abdul Hakim (2006: 34-50) states that the planned revenue is measurable rationally estimate that can be searched for any source of income, while the budgeted expenditure on any post/article is the upper limit of expenditure.

Third, the country's financial justice. Financing can be done through the mechanism of government taxes and fees borne by all levels of society, for which the government must allocate a fair use to be enjoyed by all communities without discrimination in service delivery.

Fourth, the efficiency and effectiveness of state finances. Funds are available to be used in the best possible to produce enhanced customer service and maximum welfare for the benefit of society. Therefore, according to Abdul Hakim (2006: 4578) to control the level of efficiency and effectiveness of the budget, the planning needs to be Clearly defined goals, objectives, outcomes and community benefit to be derived from an activity or project can be saved.

Fifth, the country's financial formats. Basically, the state finance the budget deficit are prepared on the terms of format (deficit budget format). The difference between revenues and expenditures resulted in a surplus or a deficit budget. This is confirmed Bappenas (2002: 56-58) that when there is a surplus, the state may establish a reserve fund, whereas in case of deficit, can be covered through loans and financing sources or sovereign bonds issued in accordance with the provisions of applicable law.

State finances organized approach to performance includes the following matters: (1) The targets are expected expenditures by function; (2) The standard of service expected and the estimated unit cost components of the activities concerned; and (3) The portion of financial income countries that finance general administration, operation and maintenance expenditures, and capital expenditures/development.

To measure the financial performance of the government, then developed a standard expenditure analysis, benchmarks of performance and cost standards. Standard expenditure analysis is an assessment of the fairness of the workload and cost of an activity, and is a measure of the performance is a measure of the success Achieved at each organizational unit of the government, while the meaning of the standard cost is the price of unit costs applicable to each area. 
In the framework of the arrangement accountability of state finances, there are several criteria to be developed on the sources of state revenue. Nurdjaman Arsjad, et.al. (1992: 45-52) detailing these criteria, namely:

(1) criteria for the results to be sufficient requires that the funds received great acceptance and sufficient for the purposes of government. Therefore, not many types of acceptance, but the results and potential;

(2) criteria for fair and equitable distribution, in terms of dimensions: an upright (or a large level of income); Landscape (source charges apply); and geographic (rise of the location where the levy was imposed). This criterion starts on the benefit principle and the principle of power endure. The benefit principle requires that the amount of levy equal to the benefits received, while the bear is the imposition of power principle must be based on a person's ability to pay fees;

(3) The criteria for administrative ability, every different kind of reception in administrative tools. Central tax, while taxes and levies, usually simple; and

(4) The tax effect of the economic criteria, in order to note the effect on the allocation of resources, because there are charges that could reduce the capability of production and investment, there are also encouraging the production and investment activities. In terms of the efficiency of the levies to encourage economic activity.

Public finances in Islam, as stated al-Mawardi (1996: 215), the existing government revenues in the state coffers are stored in separate posts (systemic administration) and spent based on their respective needs. If a post certain categories is insufficient to meet spending be scheduled by these categories, the authorities can borrow budget of another post. Initial financial administration system is what is now known as the financial federalism. Financial operations carried out, in general, by a unit of local finances in the branches of his province. Revenue from each province used to finance the province. If the local finance is smaller than local revenues, the governor sent the rest to finance the center. On the other hand, if the financing exceed revenues, the excess of the other provinces or the central finance diverted to meet the shortfall.

Thus, the system of wealth distribution is the responsibility of the country's financial institutions are managed by the existing financial condition and authority of this institution in distributing them in accordance with their respective goals (Aan Jaelani, 2006). Al-Mawardi (1996: 213-214) asserted that the responsibility of financial institutions on state revenues must be distributed to the public interest. Treasure that is rightfully financial institutions are classified into two parts, the treasure is only kept in the treasury of the state treasury for specific purposes, and treasure into government financial assets obtained from various sources of state revenue.

In spending public finance criteria that aim as a priority community needs are sourced from government revenues. The fulfillment of these needs is fard kifayah (social obligations) for the whole of society is the duty of the government to fulfill it.

In the context of public welfare, Shatibi (1975: 10), that there are other criteria for public expenditure, the objectives of Shariah that must be protected to improve the welfare of the community. If grouped, public interest, there are three categories items, namely primary (dharuriyat), secondary (hajiyat) and complement (tahsiniyat). While the objectives of Shariah that must be protected by the government include: the maintenance of religion (din), soul (nafs), intellect ( 'aql), 
descent (nasl), and property ( $\mathrm{mal}$ ). Shatibi economic philosophy of this implies that public finances are managed in the form of government spending is intended to meet reviews these objectives.

In public finance, al-Mawardi (1996: 176) explains that zakat be one of the financial instruments used for public expenditure as part of the government's sources of income incurred to meet the needs of the community ( 8 groups mustahiq). The relationship between government revenue and expenditure is illustrated al-Mawardi (1983: 266-267), that any decline in public wealth is to increase of the wealth of the country, and any decrease in the wealth of the country is the increase of public wealth in.

It shows, public spending is an effective tool to divert economic resources. The statement also suggests that public spending will increase of the income of society as a whole. Thus, government spending has been instrumental in improving the welfare of the community.

\section{E. Conclusion}

Public financial management should be conducted in a transparent and accountable, especially in the preparation, implementation, and accountability. Public financial management have economic and religious dimension aimed at public welfare. Today, although the mechanism or the management of the state budget in Indonesia underwent a reform, among others, the laws on state finances, changes in the budget management of the system of balanced budgets into a system of performance-based budgeting, change the type of budget from the regular budget and development budget into the regular budget only, and other changes indicate their painstaking efforts of the government in managing public finances.

Budget management aims to create a welfare society by taking into account the public interest through the provision of facilities and supporting facilities, and the management of state revenue in accordance with applicable regulations. The state's role in the management of public finance aims to create justice and provide social security to the community. To realize these goals, the necessary facilities and public facilities as well as strict supervision by state officials who are competent and credible in ensuring the distribution of public revenue accurately and fairly. 


\section{BIBLIOGRAPHY}

Abdullah, Taufik (ed.) (1987), Sejarah dan masyarakat: Lintasan historis Islam di Indonesia, Jakarta, Yayasan Obor Indonesia.

Abimanyu, Anggito (2004), Format anggaran terpadu menghilangkan tumpang tindih, Kompas, Mei 2004.

Aghnide (1969), Mohammedan theories of finance, New York, McGraw-Hill, Inc.

Ahmad, Ziauddin (1989), Public finance in Islam, IMF, IMF Working Paper.

Akram Khan, Mohammad (2009), Public finance in Islam: A bibliography of works in English), Jeddah, Islamic Economics Research Centre King Abdul Aziz University.

Al-Mawardi, Abu Hasan Ali (1996), Al-Ahkam al-sulthaniyah wa-wilayat al-diniyah, Beirut, Dar al-Fikr.

Al-Mawardi, Abu Hasan Ali (1983), Nashihah al-muluk, Kuwait, Maktabah alFallah.

Arsjad, Nurdjaman, et.al. (1992), Keuangan Negara, Jakarta, Intermedia.

Azmi, Sabahuddin (2002), Islamic economics: public finance in early Islamic thought, New Delhi, Goodword Books.

Balaji, 'Abd al-Salam (2000), Al-Maliyat al-'ammah 'inda al-Mawardi wa-Ibn Khaldun, al-Mansurah, Dar al-Kalimah li al-Nashr wa al-Tawzi'.

Bappenas (2002), Public good governance: Sebuah paparan singkat, Jakarta, Sekretariat Pengembangan Public Good Governance.

Buchanan, J.M. (1967), Public finance in democratic process, Chapel Hill, N.C., University of North Carolina Press.

Choudhury, M.A. (1992), The foundation of Islamic political economy, London, Eng., Macmillan \& New York.

Choudhury, M.A. (1993), The principles of Islamic political economy: A methodological enquiry, London, Eng., Macmillan \& New York.

Edgeworth, Francis Y. (1897), The pure theory of taxation, Economic Journal, 7.

Faridi (1983/1403), Theory of fiscal policy in an Islamic state, Journal Res. Islamic Economic, 1(1). 
Ghadi, Yasin (1994), Al-amwal wa al-amlak al-'ammah fi al-Islam wa hukm ali'tida' 'alaiha, Mu'tah: Mu'assasah Ram.

Glazer, Amihai \& Rothenberg, Lawrence (2001), Why government succeeds and why it fails, Cambridge MA, Harvard University Press.

Hakim, Abdul (2006), Reformasi pengelolaan dan pertanggungjawaban keuangan daerah, Yogyakart, Fakultas Ekonomi UGM.

Ibn Taymiyah (n.d.), Al-Hisbah fi al-Islam aw wadzifah al-hukumat al-Islamiyah, Madinah, Islamic University.

Iqbal, Zafar (2003), An Islamic perspective on public finance, University of South Australia.

Irfan Rana (1977), Economic system under Umar the Great, Lahore.

Islahi, Abdul Azim (2004), Contributions of muslim scholars to economic thought and analysis (11-905 A.H./632-1500 A.D), Jeddah, IERC King Abdul Aziz University.

Jaelani, Aan (2006), Masyarakat Islam dalam pandangan al-Mawardi, Bandung, Pustaka Setia.

Jaelani, Aan (2013), Institusi pasar dan hisbah: Teori pasar dalam sejarah pemikiran ekonomi Islam, Cirebon, Syari'ah Nurjati Press.

Julayd, Mahmud (1995/1415), Qira'at fi al-maliyat al- 'ammah fi al-Islam, Jeddah: IDB-IRTI.

Karim, Adiwarman Azwar (2006), Sejarah pemikiran ekonomi Islam, Jakarta, Rajawali Pers.

Krippendorf, Klaus (1991), Content analysis, Translated by Faridj Wajidi (1991), Analisis isi, Jakarta, Rajawali Press.

Mangkoesoebroto, Guritmo (1999), Ekonomi public, Yogyakarta, BPFE.

Mishra, Ramesh (2000), Globalization and the welfare state, London, McMillan.

Muhadjir, Noeng (1998), Metodologi penelitian kualitatif, Yogyakarta, Rake Sarasin.

Musgrave, Richard A. (1959), The theory of public finance, New York, McGrawHill.

Musgrave, Richard \& Peacock, Alan (eds.) (1958), Classic in the theory of public finance, New York, Macmillan. 
Nazir, M., (1984), Metode penelitian, Jakarta, Ghalia Indonesia.

Pigau, A.C. (1951), A study in public finance, London, Macmillan.

Ramsey, F.P. (1927), A contribution to the theory of taxation, Economic Journal, 37.

Rossen, Harvey S. \& Gayer, Ted (2008), Public finance, New York, McGraw-Hill.

Rossen, Harvey S. (2002), Public finance: Essay for the encyclopedia of public choice, CEPS Working Paper No. 80, March, Princeton University.

Salanie, Bernard (2000), Microeconomics of market failure, Cambridge MA, MIT Press.

Salomo, Roy V. (1998), Public expenditure management handbook, Washington, D.C., The World Bank.

Salomo, Roy V. (2003), Anggaran yang berorientasi pada kinerja dan kepemerintahan yang baik, Jurnal Forum Inovasi, 5, Desember-Februari.

Samuelson, Paul A. (2008), Economics, New York, McGraw-Hill Book Company.

Samuelson, Paul A. (1954), The pure theory of public expenditure, Review of Economics and Statistics, 36.

Shemesh, Ben (1965), Taxation in Islam, Leiden, E.J. Brill.

Siddiqi, M. Nejatullah (1992/1413), Teaching public finance in Islamic perspective, Jeddah, Centre for Research in Islamic Economics King Abdul Aziz University.

Siddiqui, S.A. (1965), Public finance in Islam, Lahore, Sh. Muh. Ashraf.

Soediyono R. (1992), Ekonomi makro pengantar analisis pendapatan nasional, Yogyakarta, Liberty.

Soetrisno PH (1981), Dasar-dasar ilmu keuangan negara, Yogyakarta, FE-UGM.

Suharto, Edi (2005), Membangun masyarakat memberdayakan rakyat: Kajian strategis pembangunan kesejahteraan sosial dan pekerjaan sosial, Bandung, Refika Aditama.

Suparmoko, M. (2003), Keuangan negara: Dalam teori dan praktek, Yogyakarta, BPFE.

Syatibi, Abu Ishaq (1975), Al-muwafaqat fi ushul al-Syari 'ah, Cairo, al-Maktabah alTijaniyah al-Kubra. 
Tjokroamidjojo, Bintoro (1995), Pengantar administrasi pembangunan, Jakarta, PT Pustaka LP3ES Indonesia.

Winer, S. \& Shibata, H. (eds.) (2002), Political economy and public finance: The role of political economy in the theory and practice of public economics, Cheltenham U.K., Edward Elgar Publishers.

Winer, Stanley L. \& Hettich, Walter (2004), structure and coherence in the political economy of public finance, Oxford Handbook of Political Economy, Nopember 16. 